\& Webster, I928), may adversely affect the fertility of stock receiving heavy supplements of such greenstuffs as kale, through depression of thyroid function, must also not be forgotten.

\title{
REFERENCES
}

Asdell, S. A. (1949). F. Dairy Sci. 32, 60.

Bacharach, A. L. (1940). Brit. med. $\mathcal{F}$. i, 890 .

Barrie, M. M. O. (1937). Lancet, 233, 25 I.

Bartlett, S., Folley, S. J., Rowland, S. J., Curnow, D. H. \& Simpson, S. A. (1948). Nature, Lond., I62, 845 .

Bennetts, H. W. (1944). F. Dep. Agric. W. Aust. 2r, 104.

Bennetts, H. W., Underwood, E. J. \& Shier, F. L. (1946). Aust. vet. F. 22, 2.

Biskind, M. S. (1946). Vitamins and Hormones, 4, 147.

Biskind, M. S. \& Biskind, G. R. (1942). Endocrinology, 31, 109.

Chesney, A. M., Clawson, T. A. \& Webster, B. (1928). Fohns Hopk. Hosp. Bull. 43, $26 \mathrm{r}$.

Curnow, D. H., Robinson, T. J. \& Underwood, E. J. (1948). Aust. F. exp. Biol. med. Sci. 26 , I7 I.

Dorfman, R. J. ( I 948). Recent Progr. Hormone Res. 2, I 70.

Evans, H. M. \& Bishop, K. S. (1922). F. metab. Res. I, 335.

Friedman, M. H. \& Turner, W. A. (1939). Yearb. U.S. Dep. Agric. p. 482.

Gyorgy, P. (1948). Recent Progr. Hormone Res. 2, 171.

Herz, R. (1945). Endocrinology, 37, I.

Herz, R. (1948). Recent Progr. Hormone Res. 2, 161.

Marrian, G. F. \& Parkes, A. S. (I930). Proc. roy. Soc. B, 105, 248.

Mason, K. E. (1944). Vitamins and Hormones, 2 , 107.

Moore, C. R. \& Samuels, L. T. (1931). Amer. F. Physiol. 96, 278.

Mulinos, M. G. \& Pomerantz, L. (1940). F. Nutrit. 19, 493.

Mulinos, M. G. \& Pomerantz, I. (1941). Endocrinology, 29, $55^{8}$.

Segaloff, A. \& Segaloff, A. (1944). Endocrinology, 34, 346.

Singer, E. (x936). F. Physiol. 87, 287.

Singher, H. O., Kensler, C. J., 'Taylor, H. C. Jr., Rhoads, C. P. \& Unna, K. (1944). F. biol. Chem. 154, 79.

Smith, C. A. (1947). Amer. F. Dis. Child. 73, 243.

\section{Nutrition and Viable Young}

\section{By A. St G. Huggetr, St Mary's Hospital Medical School, Praed Street, London, W.2}

In its widest sense the word 'fertility' covers the ability of the species to reproduce itself. In the strictest sense it applies to the production by the gonads of healthy zygotes capable of cross-fertilization and production of fertilized ova which can fructify to produce at birth or hatching healthy young of the species. It is clear, therefore, that the strictest sense is the narrower but the primary and more important meaning of the word. From the scientific, the medical and the sociological aspects the wider meaning covering the eventualities during life in the uterus or in the egg is, however, needful of consideration, if only because the life of the fertilized ovum lends itself to study by several different techniques and also is the ultimate object of fertility and reproduction.

\section{Malnutrition in civilian populations}

There is considerable evidence that, under conditions of deprivation such as occurred in Europe during the last war, there is both a depression in the birth rate, in the average birth weight, an increase in prematurity, an increase in the abortion rate and a decrease 
in conception rate. Interestingly enough, there is a decrease in incidence of the toxaemias of pregnancy, one of the major causes of human death in utero.

Antonov (1947) reported on the conditions during the siege of Leningrad in 1942. This lasted from August 194I to January 1943. The encirclement was worst between September 194I and February 1942. In this period the highest bread ration was $500 \mathrm{~g}$., and the average $400 \mathrm{~g}$./day; there was gross deficiency of vitamins; $49 \%$ of the infants born weighed under $2.5 \mathrm{~kg}$. The total morbidity for newborn infants was $32 \%$; the mortality was $9 \%$ for infants at term and $30 \%$ for premature infants.

Clement Smith surveyed the Dutch population in the summer and autumn of 1945 (Smith $\mathrm{I} 947 a, b$ ). His results in Rotterdam showed that four periods could be considered, pre-war, pre-hunger, hunger and gross hunger. The hunger period was from September 1944 to November 1944, and gross hunger from December 1944 to March 1945. During these two periods $50 \%$ of women had amenorrhoea. The weekly conception rate in the four periods was 206, 230, I82 and 93. There was an increase in abortion and miscarriage rate from $\mathrm{I} \cdot 67 \%$ pre-war to $2.2 \%$ in the hunger period and $3.7 \%$ in the post-hunger period (these children being conceived mainly in the hunger and gross hunger periods). Between I January and I April I 945 (the gross hunger period), the incidence of malformations was $2.42 \%$ (compared with $\mathrm{I} \cdot 36 \%$ pre-war).

Information which I obtained through the courtesy of Prof. S. van Creveld of Amsterdam and of Prof. Jooste of Leiden, while visiting Holland in 1946, confirms the findings of Smith. The energy value of the diet between September I 944 and May 1945 was 500 Cal. daily. This was supplemented with sugar beet, a definitely indigestible food. The diet of hospital sisters and nurses was supplemented up to $1000 \mathrm{Cal}$. in all classes of foodstuffs. The nurses were examined regularly by questionnaire. During the hunger and gross hunger periods, of 289 who previously had menstruated normally $42 \%$ had amenorrhoea and $19 \%$ irregular menses. Microcurettings in patients with amenorrhoea showed histological proliferation, but only that caused by ovarian oestrone (folliculin) and no signs of corpus luteum action, suggesting a true suppression of ovulation due to the depleted rations. The physical signs of wasting and malnutrition were marked.

\section{Effects of nutrition}

Nutrients, by their presence or absence, can affect the oestrous cycle and ovulation, the urogenital tract and implantation and the development of the placenta and of the foetus itself.

\section{Interference with oestrous cycle and ovulation}

It has already been shown how gross deprivation of total foodstuffs in women suppresses the menstrual cycle and ovulation.

Experimental deficiency of vitamin A also suppresses ovulation in animals (McCollum, Orent-Keiles \& Day, 1939). Deficiency of the vitamin B complex has a similar effect, and Heard \& Winton (1939) have used this property for the assay of gonadotrophin. Its administration to mature rats made experimentally anoestrous by such a diet is effective in restoring oestrus.

Deficiency of vitamin $\mathrm{E}$ does not interfere with ovulation and implantation. 


\section{Interference with the urogenital tract and implantation}

One of the outstanding actions of vitamin A deficiency is the generalized metaplasia of epithelial surfaces of mucous membranes to stratified epithelium. This has been described in both animals and infants by Wolbach (1937). Evans \& Bishop (1922) showed that in the rat with mild deprivation the oestrous cycle goes on, but the vaginal swab is clouded by keratinization throughout the cycle. The occurrence of copulation is the main way of recognizing oestrus in the continuous keratinization of the vagina throughout the cycle. Usually the foetus goes to full term but is unable to live because the birth mechanism is upset by the deficiency. In some cases of severe deficiency Evans \& Bishop noted absorption of the foetus. Where the foetus is born alive it often has congenital cataract (Zilva, Golding, Drummond \& Coward, I921). It is to be noted that the optic lens is embryologically an epithelial structure.

Green, Pindar, Davis \& Mellanby (I93I) showed that during pregnancy rats on a vitamin A-deficient diet acquire infections in utero which cause foetal death and maternal septicaemia. This is parallelled in women; there was an increased incidence of puerperal sepsis in women deprived of vitamin A compared with controls.

\section{Interference with the implantation site}

Vitamin E deficiency does not affect rats before the 8th day from copulation, implantation occurring at the 5 th day. Haemorrhages occur initially at the placental areas followed by failure of mesodermal development in the placenta and foetal bloodforming tissues. Foetal death follows with necrosis and absorption of everything except the decidua basalis which shows as small bodies at the implantation sites (Evans, I932).

There are similarities between the action of vitamin $\mathrm{E}$ in causing foetal destruction and the changes in the placenta when the foetus of the rat is destroyed by experimental trauma (Huggett \& Pritchard, I945; Pritchard \& Huggett, 1947). In both, the changes in the placenta result from destruction of the mesodermal tissues and of allantoic blood flow; in both, there is some growth of the ectodermal portion of the placenta; in both, early foetal death (before the Ioth day), either through trauma or from vitamin $\mathrm{E}$ deficiency, results in absorption of the foetal remains, but the trophoblastic placenta stays in position and is delivered at full term (Newton, 1935). It would appear from the results of these experiments that the trophoblast is nourished largely from the maternal blood stream. It can actually grow after foetal death and when the mesoderm and allantois are dead or dying. This occurred both in the experiments of Evans (1932) with vitamin E and in those of Huggett \& Pritchard (1945) and of Pritchard \& Huggett (1947) with trauma.

Prenatal death can be due to agents other than nutrition factors acting on the placental transport system for nutrients. The site of action determines the after-effects.

In rats at the Ioth day of pregnancy foetal trauma kills the foetus, but the trophoblast grows till the $17^{\text {th }}$ day and then collapses with maternal haemorrhage. The decidua basalis remains normal. In traumatic death at the $15^{\text {th }}$ day the foetus dies, but the trilaminar placenta grows normally and is delivered at full term. Oestrone yields another type of death. It causes acute necrosis of the placenta and decidua at the 
Ioth day but is without effect at the ${ }^{5} 5^{\text {th }}$ day. Ovariectomy has a similar action causing mainly acute decidual necrosis and foetal death. The follicle-stimulating hormone from pregnant mares' serum causes decidual hypertrophy with, however, ischaemia and necrosis. The foetus dies leaving the trophoblast growing. Nutrient deficiencies acting on the decidua, such as that of vitamin $A$, would be expected to kill the foetus secondary to placental death, whereas deficiencies such as that of vitamin $E$ acting mainly on foetal haematopoietic organs would leave the decidua and trophoblast intact.

It is of interest that Chesley (193I) described a lethal gene in rats giving a short tail and failure of development of the mesoderm. This results in complete absorption of foetus and trophoblast. Many cases of spontaneous death in utero must be attributed to lethal genes rather than to nutritional factors (Hammond, I94I).

It would be stretching the point to include erythroblastosis foetalis and the rhesus factor in this consideration of nutrition and foetal death.

\section{Interference in the developing foetus}

Zilva et al. (1921), as already mentioned, showed that deficiency of vitamin A caused cataract in foetuses. Warkany and his colleagues demonstrated that rats on a diet deficient in riboflavin acquired many congenital deformities, cleft palate, brachydactyly, incomplete closure of chest, diminution in number and ossification of limb bones, diminution of ossification of skull and jaws and thyroid changes. These deformities only occurred in rats deprived during the first days of pregnancy. The effect was fairly immediate and, if deprivation was postponed till later in pregnancy, no deformities followed. It would appear that riboflavin is essential for certain enzyme changes occurring in the foetus in connexion with these ossifications but is not essential for enzyme actions later in pregnancy. It is specific (Warkany \& Nelson, I94r; Warkany, Nelson \& Schraffenberger, 1942, 1943). In this connexion one can refer to the action of German measles in the 2nd but not in later months of pregnancy. Children born of mothers who had rubella at the 2nd month are born with congenital cataract and congenital heart lesions. The virus interferes with the metabolic enzyme systems concerned with the building of these particular tissues.

Deficiency of manganese produces in rats imperfect lactation and prenatal mortality (Orent \& McCollum, I93 I; Daniels \& Everson, 1935). There is no evidence of manganese deficiency in humans.

\section{Toxaemias of pregnancy}

Eclampsia and its associated diseases can kill the foetus in utero. The cause of the toxaemias is unknown; as has been already mentioned, the incidence in Holland was diminished with decreased rations. This was also the experience in Belgium during the occupation by the German forces. Whether the primary cause is dietetic or toxic, it is stated that the incidence of toxaemias is diminished by an increase in calcium intake (Theobald, 1937). Similar considerations apply to the toxaemias of cattle and sheeptheir cause is unknown, but their severity can be altered by alteration of rations. 


\section{Conclusions}

The results of gross malnutrition and deprivation of foodstuffs can therefore be due to some of these individual nutrient deficiencies, in so far as animal results apply to man. They can be due to other individual dietary deficiencies, they can be due to the algebraic effect of several deficiencies. Still more, of course, gross deprivation of protein and fats can be expected to cause such a general depression of bodily activity and vigour that fertility will fall. These last effects have, however, not been analysed quantitatively, apart from factors such as lysine needed for growth in general.

\section{REFERENCES}

Antonov, A. N. (1947). F. Pediat. 30, 250.

Chesley, P. (1931). Proc. Soc. exp. Biol., N.Y., 24, 437.

Daniels, A. L. \& Everson, G. J. (1935), F. Nutrit. 9, 191.

Evans, H. M. (1932). F. Amer. med. Ass. 99, 469.

Evans, H. M. \& Bishop, K. S. (1922). Anat. Rec. 23, I 7.

Green, H. N., Pindar, D., Davis, G. \& Mellanby, E. (I93I). Brit. med. F. ii, 595.

Hammond, J. (1941). Biol. Rev. 16, 165.

Heard, R. D. H. \& Winton, S. S. (1939). F. Physiol. 96, 248.

Huggett, A. St. G. \& Pritchard, J. J. (1945). Proc. R. Soc. Med. 38, 26 r.

McCollum, E. V., Orent-Keiles, E. \& Day, H. G. (1939). The Newer Knowledge of Nutrition, p. $53^{8}$. New York: Macmillan Co.

Newton, W. H. (1935). 7. Physiol. 84, 196.

Orent, E. R. \& McCollum, E. V. (193I). F. biol. Chem. 92, 65 I.

Pritchard, J. J. \& Huggett, A. St G. (1947). F. Anat., Lond., 81, 2 I2.

Smith, C. A. (x947a). Y. Pediat. 30, 229.

Smith, C. A. (1947b). Amer. F. Obstet. Gynec. 53, 599.

Theobald, G. W. (1937). Lancet, 232, 1397.

Warkany, J. \& Nelson, R. C. (194I). Anat. Rec. 79, 83.

Warkany, J., Nelson, R. C. \& Schraffenberger, E. (1942). Amer. F. Dis. Child. 64, 860.

Warkany, J., Nelson, R. C. \& Schraffenberger, E. (1943). Amer. F. Dis. Child. 65, 882.

Wolbach, S. B. (1937). F. Amer. med. Ass. 108, 7.

Zilva, S. S., Golding, J., Drummond, J. C. \& Coward, K. H. (1921). Biochem. F. 15, 427.

\section{Nutrition and Human Fertility}

\section{By G. I. M. Swyer, University College Hospital Medical School, University Street, Gower Street, London, W.C.I}

The influence of nutrition on reproduction, though extensively studied in the lower animals, has been the subject of few critical investigations in man. Widely divergent views are held, ranging from the completely sceptical to the unreasoningly enthusiastic, and the lack of fully substantiated basic data makes it difficult for the unbiased student to find the most probable of the several possibilities presented. The attempt of this paper will be to discuss a few aspects of this broad subject, the emphasis throughout being placed on probability.

\section{Starvation}

At the outset, taking a world view, one is faced with what appears to be a paradox: in the west the relatively well-nourished populations have in general a lower birth rate and tend to be static or declining, while in the east malnutrition is rife, but the birth 